\title{
Gutta-percha points surface alterations after sodium hypochlorite disinfection
}

\author{
Alterações superficiais na guta percha após desinfecção com hipoclorito de sódio
}

Selma Maria Santos Moura BRITO ${ }^{1}$, Rafaela Andrade de VASCONCELOS ${ }^{1}$, Simone Helena Gonçalves de OLIVEIRA ${ }^{2}$

1 - Institute of Science and Technology - UNESP - Univ Estadual Paulista - School of Dentistry - Department of Restorative Dentistry - São José dos Campos - SP - Brazil.

2 - Institute of Science and Technology - UNESP - Univ Estadual Paulista - School of Dentistry - Department of Bioscience and Oral Diagnosis - São José dos Campos - SP - Brazil.

\section{ABSTRACT}

Considering that gutta-percha may contact the apical and periapical tissues during root canal filling, they must be disinfected to avoid the propagation of pathogenic microorganisms. Objective: The purpose of this study was to evaluate the effect of $1 \%$ and $2.5 \%$ sodium hypochlorite on the surface morphology of gutta-percha points according to the period of immersion, and to analyze the marginal sealing of root canal filling with these points. Methods: The surface morphology of 110 gutta-percha points was analyzed by scanning electron microscopy, divided into 3 groups: G1 (control), G2 and G3, respectively immersed in $1 \%$ and $2.5 \%$ sodium hypochlorite, for $30 \mathrm{~min}, 6 \mathrm{~h}, 12 \mathrm{~h}$ and $24 \mathrm{~h}$. Analysis of marginal sealing was performed on 72 single-rooted human teeth with root length of $16-18 \mathrm{~mm}$, divided into 6 groups, prepared and filled with AH Plus sealer with the points immerged in the solution, the convencional times were taken control (A and B) and during $30 \mathrm{~min}$ and $24 \mathrm{~h}$ (groups C, D, E and F). The roots received an impermeable coating on the external surface, except for the apical foramen; the roots were then immersed in India ink for $24 \mathrm{~h}$ and were made transparent. Results: The results showed increasing and progressive alteration in the surface morphology of points according to the increase in the solution concentration and period of immersion. The microleakage means obtained in mm were: $\mathrm{A}=$ 1.14; $\mathrm{B}=1.22 ; \mathrm{C}=1.17 ; \mathrm{D}=1.26 ; \mathrm{E}=1.44$ and $\mathrm{F}=1.60$. The Dunnett test and analysis of variance were application. Conclusion: It was concluded that the increase in sodium hypochlorite concentration and period of immersion of points in the solution promote gradual increasing alteration in the surface morphology of points; microleakage means of these obturations did not reveal statistically significant differences.

\section{RESUMO}

Considerando que a guta percha pode entrar em contato com os tecidos apicais e periapicais no momento da obturação, os cones devem ser desinfectados antes do uso para que não sirvam de veículo para microrganismos patogênicos. Objetivo: A proposta deste estudo foi avaliar o efeito do $\mathrm{NaOCl}$ a $1 \%$ e a $2,5 \%$ sobre a morfologia superficial dos cones de guta-percha em função do tempo de imersão e analisar o selamento marginal de canais obturados com estes cones. Métodos: Para isto, foi analisada pelo MEV a morfologia superficial de 110 cones de guta-percha principal, divididos em 3 grupos: G1 (controle), G2 e G3 imersos no $\mathrm{NaOCl} 1 \%$ e 2,5\% durante 30 min, 6, 12 e $24 \mathrm{~h}$. Para análise do selamento foram utilizados 72 dentes unirradiculados humanos com o comprimento das raízes padronizados entre 16-18 $\mathrm{mm}$, que foram divididas em 6 grupos, instrumentadas e obturadas com o cimento endodôntico AH Plus e com os cones imersos nas soluções de $\mathrm{NaOCl} 1 \%$ e 2,5\% durante 30 min e $24 \mathrm{~h}$ (grupos A, B, C e D); os tempos convencionais foram utilizados como controles (E e F). As raízes foram impermeabilizadas externamente, exceto no forame apical, imersas no corante tinta da Índia por mais de $24 \mathrm{~h}$ e diafanizadas. A leitura das microinfiltrações foi realizada pelo esteromicroscópio, as imagens obtidas eram fotografadas e salvas no computador para medir as microinfiltrações utilizando o programa Image Tool. Resultado: Os resultados mostraram alteração gradativa crescente na morfologia superficial dos cones de acordo com o aumento da concentração do $\mathrm{NaOCl}$ e do tempo de imersão. As médias de microinfiltração obtidas em $\mathrm{mm}$ foram de: $\mathrm{A}=1,17 ; \mathrm{B}=1,26 ; \mathrm{C}=1,44 ; \mathrm{D}=$ 1,$60 ; \mathrm{E}=1,14$ e $\mathrm{F}=1,22$. Através do Teste Dunnett e da análise de variância (ANOVA) não houve diferença estatisticamente significante. Conclusão: Concluiu-se que ocorre alteração gradativa crescente na morfologia superficial dos cones com o aumento da concentração e do tempo de imersão na solução estudada, e as médias de microinfiltração das obturações não apresentaram diferença estatística significante. 


\section{KEYWORDS}

Disinfection; Endodontics; Gutta-percha; Microleakage; Sodium hypochlorite.

\section{PALAVRAS-CHAVE}

Endodontia; Guta-percha; Desinfecção; Hipoclorito de sódio; Microinfiltração.

\section{INTRODUCTION}

$\Gamma$ he material that meets the requirements 1 for a satisfactory filling of root canals is the gutta-percha cones and how to come into intimate contact with the periapical tissues during filling it should be disinfected before use by a chemical method [1-3]. Although guttapercha is usually sterile during cooking, they can be easily contaminated if handled incorrectly, aerosols and physical resources during the storage process [2-4].

Chemical means are needed for disinfection of gutta-percha [1] since the physical methods of sterilization are contraindicated because the gutta-percha are thermoplastic materials $[3,5]$. Sodium hypochlorite is a substance used for disinfection of rapid bactericidal and sporicidal activity over the gutta-percha [6], but other substances are also used as ethyl alcohol, povidone iodine, glutaraldehyde, chlorhexidine, peroxide hydrogen, formaldehyde, peracetic acid $[1,2,5,7,8]$.

Several studies indicate the time required for the disinfection of cones according to the concentration of sodium hypochlorite, however, little information on how long the cones can be immersed in sodium hypochlorite solutions without suffering morphological change. Decreased traction cone of gutta-percha, increasing the elasticity of gutta-percha, change in surface texture and physical properties of cones [9] besides the formation of crystals on the surface of the cones are some of the physical changes that occur in gutta-percha after chemical disinfection [10].

Whereas cones may remain for longer than necessary for the disinfection of contact with the disinfectant solutions were evaluated for possible surface changes occurring in guttapercha when dipped in sodium hypochlorite solutions in concentrations of $1 \%$ and $2.5 \%$ for periods of time more extensive than is necessary for decontamination.

\section{MATERIAL AND METHODS}

This study was approved by the local ethics committee (076/2005PH / CEP).

This experiment was conducted to evaluate the surface morphology of gutta-percha disinfected with $1 \%$ and $2.5 \% \mathrm{NaOCl}$. We used 110 main cones of gutta-percha number 30 (Dentsply, Petrópolis, RJ, Brazil), divided into 3 groups (G1, G2 and G3) according to the concentration of sodium hypochlorite and length of stay in solution.

The control group, G1, was subdivided into three subgroups consisting of 10 cones each:

- Cones without disinfection

- Cones disinfected with sodium hypochlorite at $1 \%$ for $20 \mathrm{~min}$

- Cones disinfected with sodium hypochlorite at $2.5 \%$ for $10 \mathrm{~min}$.

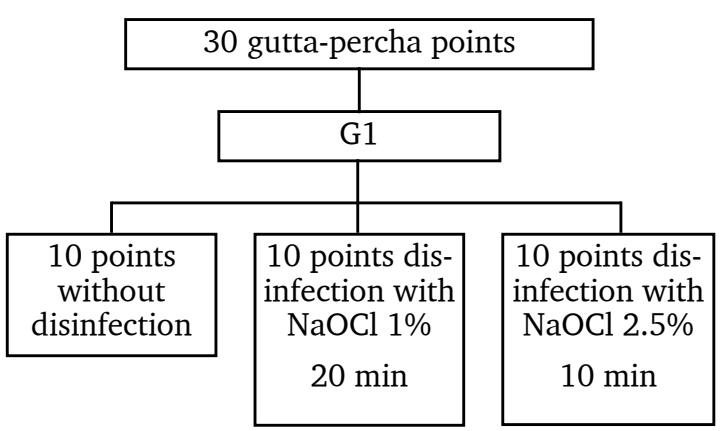

Figure 1- Control: gutta-percha points immersed for periods reported in the literature for each solution and without disinfection.

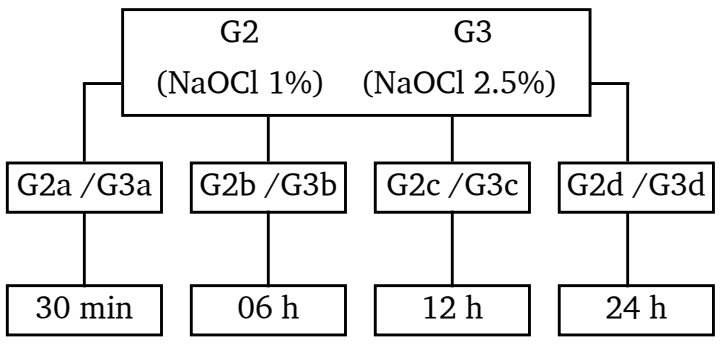

Figure 2 - Time of immersion of the gutta-percha points in the disinfectant. 
Disinfected cones in the control group follow standards specified by the literature of the concentration and residence times [3]. G2 cones were disinfected with sodium hypochlorite at $1 \%$ concentration, the subgroups consisted of 10 cones each varying the immersion time of $30 \mathrm{~min}$ (a), 6 $\mathrm{h}$ (b), $12 \mathrm{~h}$ (c) and $24 \mathrm{~h}$ (d). In G3, the cones were disinfected with sodium hypochlorite at $2.5 \%$ concentration, the subgroups also consisted of 10 cones each varying the immersion time of 30 min (a), 6 h (b), 12 h (c) and 24 h (d). After immersion times in the solutions, the cones were cut to approximately $12 \mathrm{~mm}$ from the tip, fixed in a base metal and plated with gold for analysis of surface morphology of the cones by SEM (JEOL modelo JSM 5310).

The G1 group (control) was used as standard for comparison of surface morphology of the other groups. The analysis of the morphology of cones occurred with increases of 500x to select the image location and 5000x, the central portion $2 \mathrm{~mm}$ from the tip off the cones, to be evaluated on a visual, descriptive and comparative.

For evaluation of microleakage diaphanization shutter were used 72 singlerooted human teeth. Dental crowns were removed with carborundum disks at low speed to standardize the roots between 16 and $18 \mathrm{~mm}$. The roots were instrumented by step-back technique programmed to stop making apical $1 \mathrm{~mm}$ from the apex to file $\mathrm{K}$ 30 (Maillefer - Switzerland) and scaling up to file $\mathrm{K} 45$. Abundant irrigation with $1 \%$ sodium hypochlorite was did to each instrument change. At the end of the instrument, the channels were irrigated with EDTA solution (Farmácia Biomecânica, Brazil) for $3 \mathrm{~min}$ to remove the smear layer, continuing with new irrigation $1 \%$ $\mathrm{NaOCl}$. The roots were fixed in toothpicks on wax plates utility and externally sealed with two layers of nail polish red colored (Scratch out Niasi, São Paulo, Brazil) except the cervical opening and the apical foramen.

After the $24 \mathrm{~h}$ for drying waterproofing agent, held new irrigation canals with $1 \%$ washed in water for $3 \mathrm{~h}$ and dehydrated in alcohol ascending (80, 96 and 100\%) for $1 \mathrm{~h}$ at each concentration alcohol. Held decalcification with acid and dehydration in alcohol, the roots were clarified by immersing them in methyl salicylate, completing the process of being cleared.

The reading of microleakage was performed by stereomicroscope (Oberkochen, Germany) coupled to a camera and one computer. The generated images were photographed and saved on your computer for later measure microleakage marginal $\mathrm{mm}$, using the Image Tool for Windows, version 3.0 that allows obtaining calibrated measurements with accuracy and reproducibility and ease of use without requiring devices. Sophisticated computer, enabling an analysis at high resolution, sharpness, and excellent visibility.

Microleakage was compared by the Dunnett's test at a significance level of 5\% and two-way analysis of variance was applied to evaluate the influence of sodium hypochlorite concentration at two different periods on microleakage.

\section{RESULTS}

The microabrasion technique is considered minimally invasive procedure $[1,3,4]$. Special care is needed during the procedures to avoid removing extra tooth structure. The microabrasion treatment of selected cases requires the correct disease diagnosis [28]. A variety of etiologies can cause color changes in the dental enamel. Since the aim of microabrasion treatment is to preserve healthy tooth structure, the esthetic result might be a consequence of a successful superficial enamel removal.

The concentration and time of used acid significantly influences the superficial enamel removal because the demineralization degree is directly dependent on it [3]. The acids associated with course particles increase the abrasive potential, removing the enamel irregularities of fluorosis stains [29]. Other factors related to 
$\mathrm{NaOCl}$ to rehydrate the dentinal walls and dry with absorbent paper points. Were selected the main cone 30 with locking $1 \mathrm{~mm}$ apical foramen, the processing according to the cones selected along with the main auxiliary cones $\mathrm{XF}$ and FF given. It should be emphasized that the cones were also auxiliary $\mathrm{NaOCl}$ immersed in solutions of $1 \%$ and $2.5 \%$ in the same time. Main cones remained in the solutions according to the group which they belonged. The roots were divided into 6 groups: A, B, C, D, E and F to then be filled through lateral condensation technique active and AH Plus sealer (Dentsply, Germany).

Groups A and B were used as controls, consisting of 10 sealed with the cone roots of G1 (control), with five cones were disinfected with sodium hypochlorite at $1 \%$ for $20 \mathrm{~min}$ (A) and sealed with five cones disinfected by sodium hypochlorite at $2.5 \%$ for $10 \mathrm{~min}$ (B). The other groups were obturated with gutta-percha disinfected for $30 \mathrm{~min}$ and $24 \mathrm{~h}$ with concentrations of $1 \%$ and $2.5 \% \mathrm{NaOCl}$ (C,D,E,F).

Completed the fillings, all roots immediately received a thick layer of sticky wax (Horus-Herpo, Rio de Janeiro, Brazil) to complete the waterproofing, being deposited with a heated spatula over the entire surface of the roots, except in the apical region, leaving visible foramen.

Held by the waterproofing, the roots were immersed in dye of India (Ink Nanjing) and taken to a vacuum environment of 20 $\mathrm{mmHg}$, fostered by a bomb attached to a vacuum campânula. The roots remained in this environment for $30 \mathrm{~min}$ and then the dyes were maintained in an incubator at $37{ }^{\circ} \mathrm{C}$ for more than $24 \mathrm{~h}$.

After this period were washed in water for $24 \mathrm{~h}$, removed the layers of waterproofing external aid with a escalpe. Roots were cleared for assessment microleakage. They were then decalcified in hydrochloric acid 5\% for 20 days under constant agitation. The following were the microabrasion technique besides the pastes influenced the results, such as: the instrument of paste application and its mode (manually or mechanically applied). However, it must be highlighted that regardless of the type of instrument utilized, the surface roughness of the enamel will always be increased [30].

\section{Morphologic evaluation of the surface of gutta-percha points}

We performed a comparative analysis of the control group G1 and the change together with the experimental groups G2 and G3 and the latter with each other, watching the changing surface of the cones after immersion in each concentration of $\mathrm{NaOCl}$, the four time points studied. At the end of a checkout was performed between the cones immersed in the same period of time in both $\mathrm{NaOCl}$ concentrations.

According to the images obtained by visual analysis and comparison, we observed the presence of irregularities and depressions on the surface of the cones in all groups, but these characteristics did not differ when comparing the control group with each other without disinfection and those immersed in $1 \% \mathrm{NaOCl}$ for $20 \mathrm{~min}$ and $2.5 \% \mathrm{NaOCl}$ for 10 min, showing also similar to the images of the groups $\mathrm{G} 2 \mathrm{a}(1 \% \mathrm{NaOCl}-30 \mathrm{~min})$.

There was a gradual change and growing in the morphology of cones with increasing immersion time and solution concentration studied, i.e., the longer immersion in the solution, more irregularities were observed in G2 a, b, c, d -cones immersed in $1 \% \mathrm{NaOCl}$ for $30 \mathrm{~min}, 6 \mathrm{~h}, 12 \mathrm{~h}$ and $24 \mathrm{~h}$ respectively, the same was observed for the solution to $2.5 \%$ in $\mathrm{G} 3 \mathrm{~b}, \mathrm{c}, \mathrm{d}$ but in greater degree in the $\mathrm{NaOCl}$ to $1 \%$, that is, the longer the immersion in the solution, the greater the change and the higher the concentration (2.5\%) and longer soaking, more irregularities and depressions, observing craters on the true surface of the cones immersed in $2.5 \% \mathrm{NaOCl}$ in $24 \mathrm{~h}$ period (Figure 4 to 6 ). 

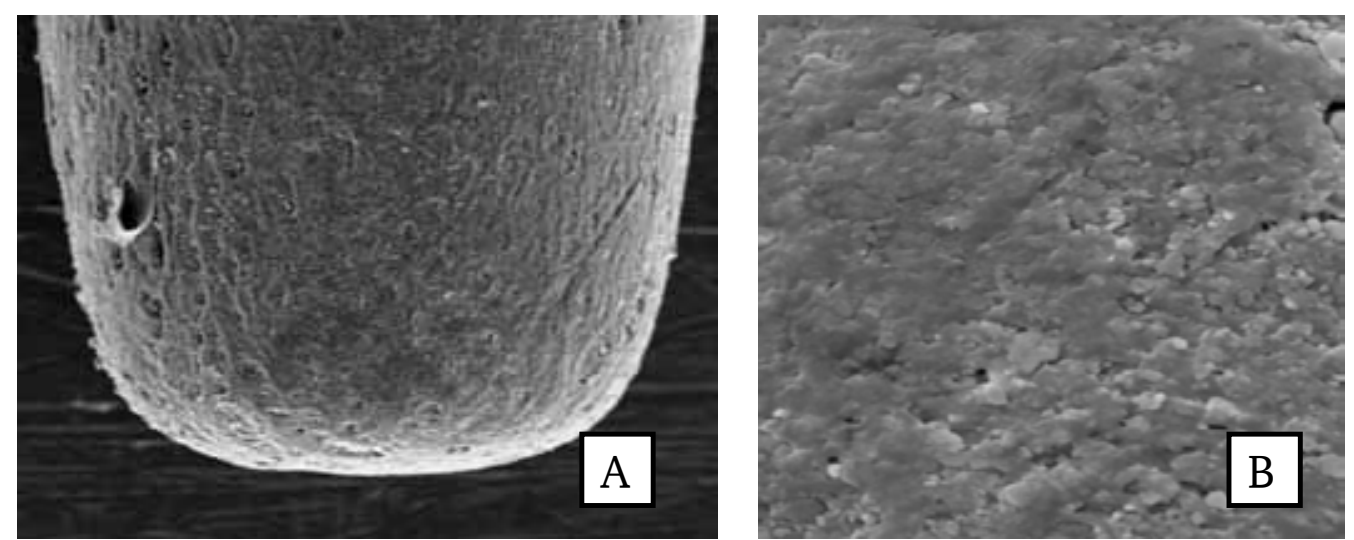

Figure 3-Aspect of the surface morphology of gutta-percha points at 500x (A) and 5000x (B) magnification.

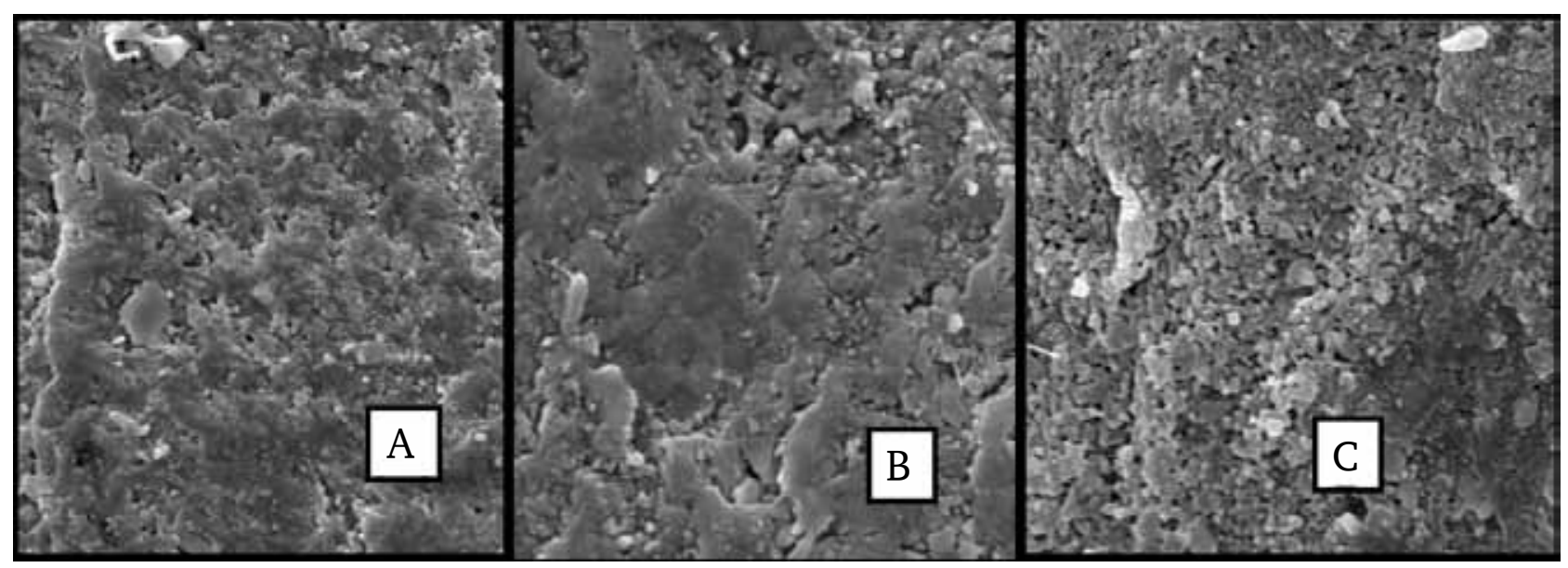

Figure 4-Group (G1): control - gutta-percha points without disinfection (A); immersed in 1\% NaOCl for 20 min (B) and immersed in 2.5\% NaOCl for 10 min (C).

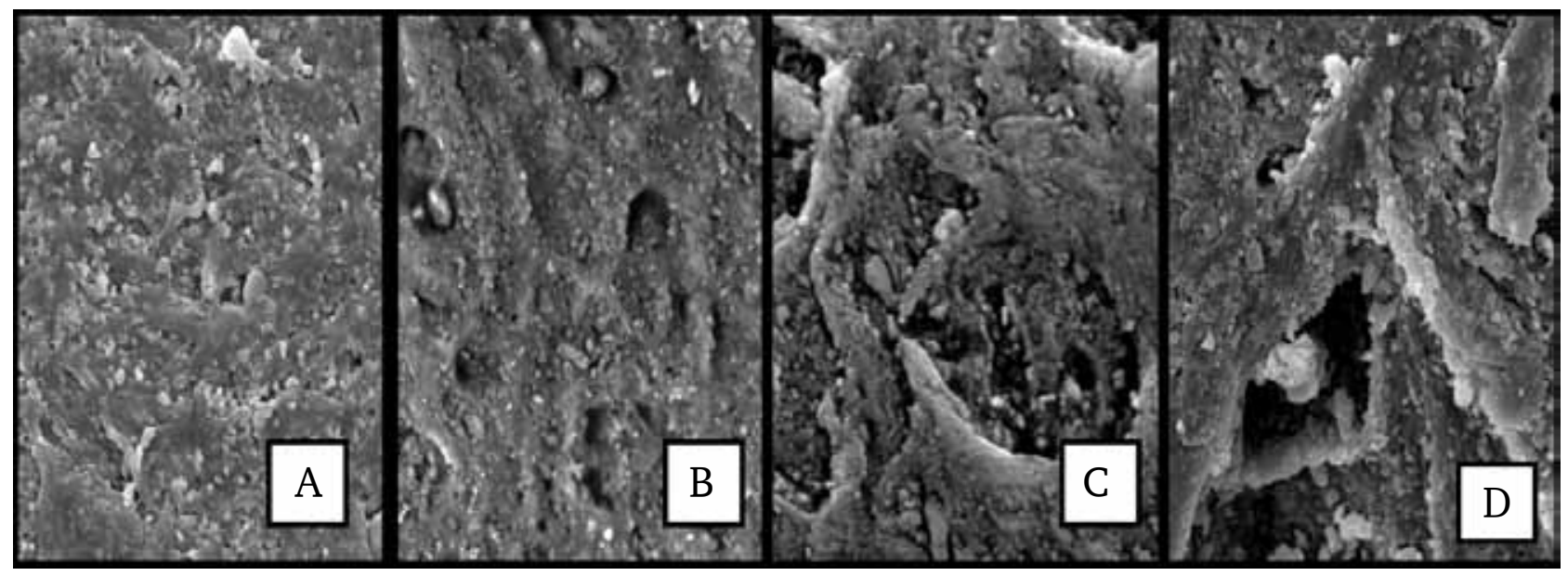

Figure 5-Group (G2): points immersed in 1\% NaOCl for 30 minutes (A), 6 (B), 12 (C) and $24 \mathrm{~h}$ (D). 

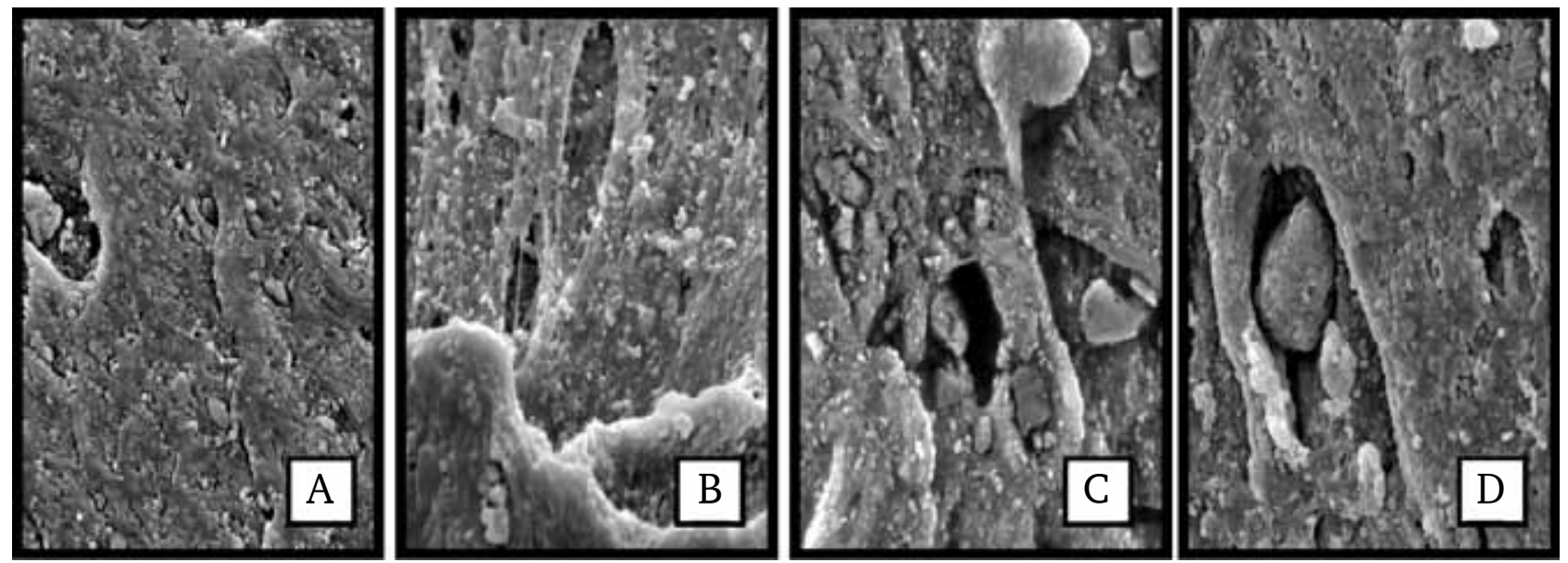

Figure 6 - Group G3: points immersed in 25\% NaOCl for 30 min (A), 6 (B), 12 (C) and 24 h (D).

\section{Evaluation of marginal microleakage in cleared teeth}

Microleakage was analyzed on a stereomicroscope; data on control (A and $\mathrm{B}$ ) and experimental groups $(\mathrm{C}, \mathrm{D}, \mathrm{E}$ and $\mathrm{F}$ ) were obtained with aid of the Image Tool software (Table 1).
Microleakage in control and experimental groups disinfected with the same concentration of solution was compared by the Dunnett's test at a significance level of 5\%. Two-way analysis of variance was applied to evaluate the influence of sodium hypochlorite concentration at two different periods on microleakage, as presented in Table 2 (figure 7 to 8).
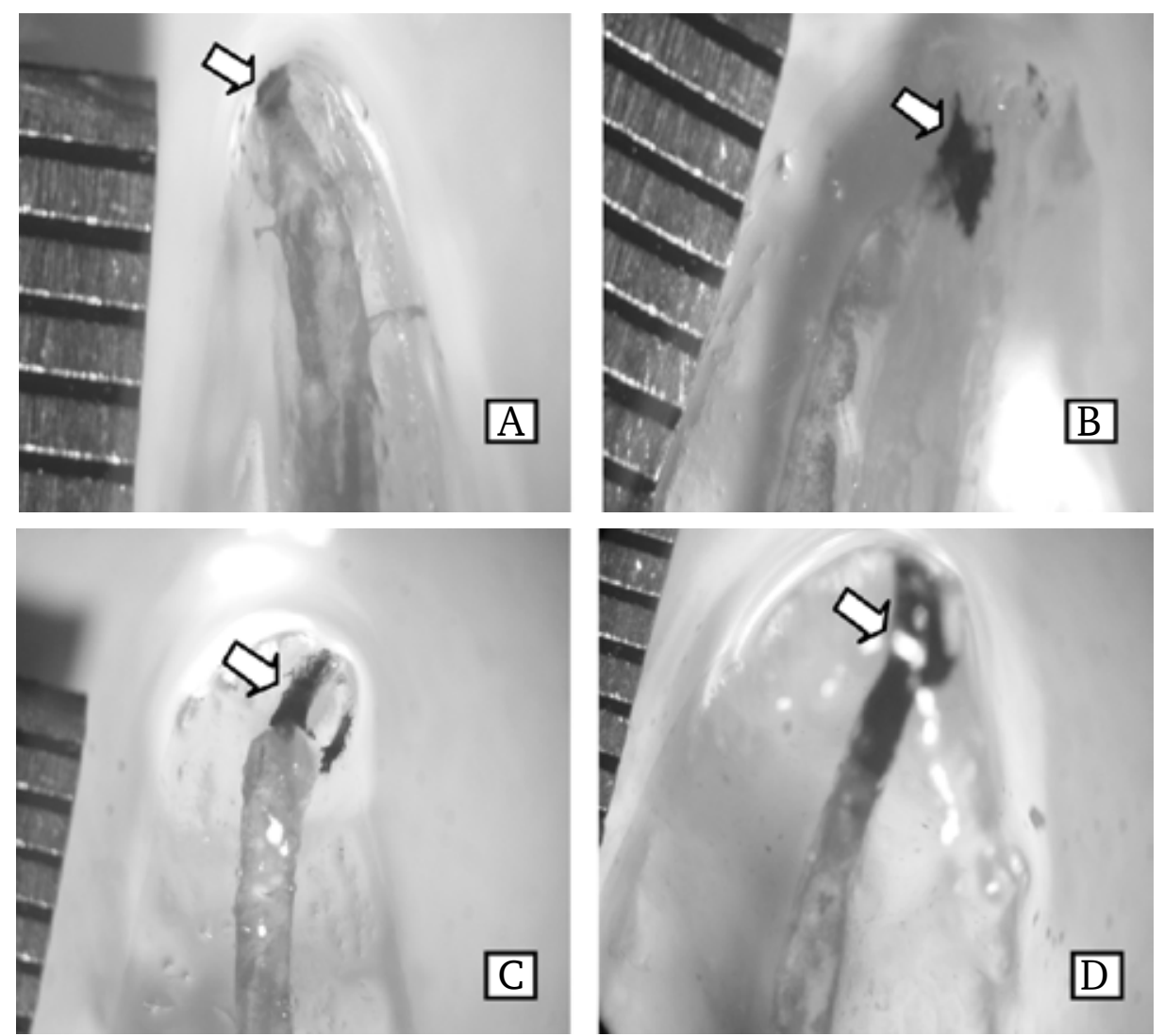

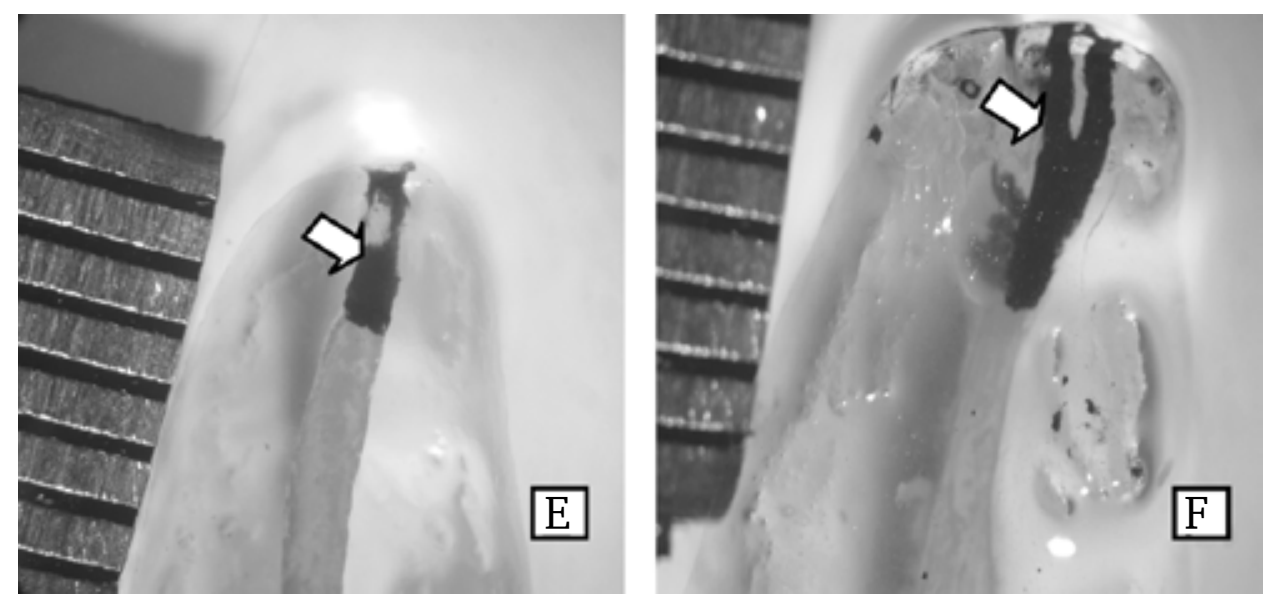

Figure 7 - Obtained images of the control group $1 \% \mathrm{NaOCl} 20$ min (A) and 25\% NaOCl 10 minutes (B).Obtained images of the groups $1 \% \mathrm{NaOCl} 30 \mathrm{~min}$ (C) and $24 \mathrm{~h}$ (D). Obtained images of the groups $25 \% \mathrm{NaOCl} 30 \mathrm{~min}$ (E) and $24 h(F)$.

Table 1 - Descriptive statistics of microleakage $(\mathrm{mm})$ data obtained in human roots, according to the four different experimental conditions and two control conditions

\begin{tabular}{ccccccc} 
Statistic & Group A & Group B & Group C & Group D & GroupE & GroupF \\
Mean & 1.142 & 1.216 & 1.175 & 1.262 & 1.443 & 1.605 \\
\hline Standard deviation & 0.501 & 0.408 & 1.022 & 0.411 & 0.896 & 1.413 \\
Minimum & 0.590 & 0.590 & 0.110 & 0.300 & 0.200 & 0.350 \\
\hline 250 Percentile & 0.595 & 0.855 & 0.200 & 1.030 & 0.800 & 0.670 \\
Median & 1.450 & 1.220 & 1.090 & 1.350 & 1.270 & 1.150 \\
\hline 750 Percentile & 1.535 & 1.575 & 2.030 & 1.620 & 2.200 & 2.340 \\
Maximum & 1.560 & 1.640 & 3.500 & 1.720 & 3.280 & 5.940
\end{tabular}

Table 2 - Two away ANOVA for the obtained data

$\begin{array}{cccccc}\text { Effect } & \text { gl } & \text { SQ } & \text { QM } & \text { F } & \text { P } \\ \text { Time } & 1 & 1.4045 & 1.40454 & 1.40 & 0.242 \\ \text { Concentration } & 1 & 0.2331 & 0.23313 & 0.23 & 0.632 \\ \text { Interation } & 1 & 0.0209 & 0.02091 & 0.02 & 0.886 \\ \text { Residue } & 56 & 56.1899 & 1.00339 & & \\ \text { Total } & 59 & 57.8485 & & & \end{array}$




\section{DISCUSSION}

Regarding the first stage of the present study, the surface morphology of images of each group, by visual comparison of gutta-percha points in control and experimental groups within and between them, revealed the presence of irregularities and depressions on the surface of points in all groups, in agreement with Goldberg et al. [11]. and Valois et al. [12] .These alterations were similar between control groups and points immersed in $1 \%$ sodium hypochlorite for $30 \mathrm{~min}$. In the other groups, increasing alterations were observed in the morphology of points between control groups without disinfection and groups immersed for 30 min (2.5\% sodium hypochlorite), 6 and $12 \mathrm{~h}$, with greater irregularity compared to points immersed in sodium hypochlorite for $24 \mathrm{~h}$, corroborating the reports of Valois et al. [12]. Molleer and Orstavik [13] also found alterations in points immersed for this period employing another disinfectant; however, Lopes et al. [7] did not find alterations in points immersed in $5 \%$ sodium hypochlorite for $30 \mathrm{~min}$. Alterations occurred increasingly with the time of immersion of points in the solutions; the deleterious effect on the morphology of points immersed in $1 \%$ sodium hypochlorite were slightly smaller compared to $2.5 \%$ sodium hypochlorite, compared to groups immersed in different concentrations for different periods; that is to say, points immersed in 1\% sodium hypochlorite showed less irregularities compared to points immersed in $2.5 \%$ sodium hypochlorite for the same periods $(30 \mathrm{~min}, 6 \mathrm{~h}$, $12 \mathrm{~h}$ and $24 \mathrm{~h}$ ). Therefore, the longer the periods of immersion, the larger was the alteration; the higher the concentration of sodium hypochlorite, the larger was the modification; and the larger the concentration and period, the larger was the surface alteration of gutta-percha points, exhibiting crater-like irregularities on the surface of points immersed in $2.5 \%$ sodium hypochlorite for $24 \mathrm{~h}$.

Table 1 displays the means and standard deviations of microleakage of the groups. According to these data, the distribution of values obtained for $1 \%$ sodium hypochlorite, regardless of the period of immersion, is similar to the corresponding control (1\% sodium hypochlorite for $20 \mathrm{~min}$ ). The same can be applied to $2.5 \%$ sodium hypochlorite compared to the control ( $2.5 \%$ sodium hypochlorite for $10 \mathrm{~min}$ ).
The mean values of microleakage found for the present sealer are close to those obtained by Souza [14] and different from some studies in the literature, being higher than the values reported by De Almeida et al. [15], yet lower compared to Sevimay and Kalayci [16]. These discordant values are possibly related to variations in methodologies for measurement of microleakage.

Observing the sum of microleakage values in each group, an increment is observed with the increase in period and in hypochlorite concentration; however, when these data were submitted to two-way analysis of variance (ANOVA), the means of microleakage did not reveal statistically significant difference, as presented in Table 2.

Regarding the interaction it can be observed that the increase in microleakage at the period of $30 \mathrm{~min}$ is close to the increase observed for the period of $24 \mathrm{~h}$, considering concentrations of $1 \%$ and $2.5 \%$ of sodium hypochlorite, thereby indicating a non-statistically significant effect $(\mathrm{p}=0.886>0.05)$. Therefore, increase in the concentration and period of immersion of points in the sodium hypochlorite solution increased the morphologic alteration in morphology and the mean of microleakage. However, analysis of values did not reveal statistically significant difference, which can be explained by the fact that the sealer probably filled irregularities of the points, as described by Valois et al. 12 However, so far it is not known whether these alterations on the points shall be compensated by the sealer without damage to root canal sealing, since Goldberg et al. [11] reported that the surface irregularities influence the quality of filling.

Considering the limitations of the proposed methodology and the obtained results, the following could be concluded: increasing the concentration of the studied solution and the time of immersion of gutta-percha points for disinfection caused morphologic alterations and comparison of root canal filling performed with gutta-percha points disinfected with the two concentrations of sodium hypochlorite, at periods of $30 \mathrm{~min}$ and $24 \mathrm{~h}$, did not reveal statistically significant difference as to microleakage values, at a significance level of $5 \%$. 


\section{REFERENCES}

1. Stabholz A, Friedman S, Heling I, Sela MN. Efficiency of different chemical agents on decontamination of gutta-percha cones. Int Endod J. 1987;20:211-6

2. da Motta PG, de Figueiredo CB, Maltos SM. Efficacy of chemical sterilization and storage conditions of gutta-percha cones. Int Endod J. 2001;34:435-9.

3. Gomes BP, Vianna ME, Matsumoto CU, Rossi VP, Zaia AA, Ferraz CC, Souza-Filho FJ. Disinfection of gutta-percha cones with chlorhexidine and sodium hypochlorite. Oral Surg Oral Med Oral Pathol Oral Radiol Endod. 2005;100:512-7.

4. Ozalp N, Okete Z, Ozcelik B. The rapid sterilization of gutta-percha cones with sodium hypochlorite and glutaraldehyde. J Endod. 2006:32(12)1202-4.

5. Grecca FS, Porto M, Fontanella VR, Scarparo RK. SEM evaluation of thermoplastic endodontic materials alterations after disinfection: a new experimental model. Microsc Res Tech. 2011;74:109-12.

6. Bloomfield SF, Miles GA. The antibacterial properties of sodium dichloroisocyanurate and sodium hypochlorite formulations. J Appl Bacteriol. 1979;46:65-73.

7. Lopes HP, Elias CN, Estrela C. Analyses of the surfaces of gutta-percha cones after the chemical sterilization. Braz Endod J. 1997;2(1):35-7.

8. Salvia ACRD, Teodoro GR, Balducci I, Koga-Ito CY, Oliveira SHG Effectiveness of $2 \%$ peracetic acid for the disinfection of gutta-percha cones. Braz Oral Res. 2011;25(1):23-7.
9. Pang NS, Jung Y, Bae K, Baek S, Lee W, Kum K. Effects of short-term Chemical disinfection of gutta-Percha cones: Identification of Affected Microbes and alterations in surface texture and physical properties. J Endod. 2007;33(5):594-8.

10. Short RD, Dorn SO, Kuttler S. The crystallization of sodium hypochlorite on gutta-percha cones after the rapid-sterilization technique: an SEM study. J Endod. 2003;29:670-3.

11. Goldberg F, Massone EJ, Pruskin E, Zmener 0. SEM study of surface architecture of gutta-percha cones. Endod Dent Traumatol. 1991;7:15-8.

12. Valois CRA, Silva LP, Azevedo RB. Structural effects of sodium hypochlorite solutions on gutta-percha cones: atomic force microscopy study. J Odontol Esthet. 2005;31:749-51.

13. Moller BE, Orstavik D. Influence of antiseptic storage solutions on physical properties of endodontic gutta-percha points. Scand J Dent Res. 1985;93(1):158-61.

14. Souza, EM. Influência dos corantes azul de metileno a $2 \%$ e rodamina B a $2 \%$ na determinação da capacidade seladora apical de diferentes cimentos endodônticos [dissertação]. Araraquara: Faculdade de Odontologia, de Araraquara, Universidade Estadual Paulista; 2004.174p

15. De Almeida WA, Leonardo MR, Tanomaru Filho M, Silva LAB. Evaluation of apical sealing of three endodontic sealers. Int Endod J. 2000;33:25-7.

16. Sevimay S, Kalayci A. Evaluation of apical selaling ability and adaptation to dentine of two resin-based sealers. J Oral Rehabil. 2005;32:105-10.

\section{Simone Helena Gonçalves de Oliveira \\ (Correspondent Author)}

Institute of Science and Technology - UNESP

Av. Eng. Francisco José Longo, 777

São José dos Campos - SP - Brasil- CEP - 12.145-000

Tel.: (55) 12 3947-9029

Date submitted: 2013 Apr 15

E-mail: simone@fosjc.unesp.br 